\title{
Effect of oxidants and antioxidants on oral health
}

\author{
Wpływ oksydantów i antyoksydantów na zdrowie jamy ustnej
}

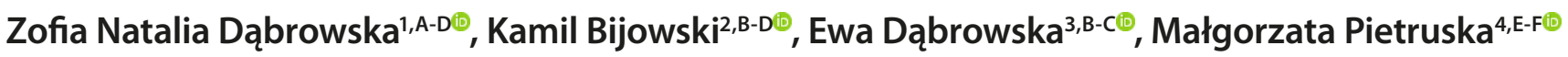 \\ 1 Doctoral studies at the Faculty of Medicine of the Medical University of Bialystok, Department of Periodontal and Oral \\ Mucosa Diseases UMwB, Białystok, Poland \\ ${ }^{2}$ NZOZ Dental Katarzyna Bijowska, Białystok, Poland \\ ${ }^{3}$ Independent Laboratory of Gerostomatology, Medical University of Bialystok, Poland \\ ${ }^{4}$ Department of Periodontal Diseases and Oral Mucosa, Medical University of Bialystok, Poland \\ A - Research concept and design, B - Collection and/or assembly of data, C - Data analysis and interpretation, \\ $D$ - Writing the article, E - Critical revision of the article, F- Final approval of article
}

Dąbrowska ZN, Bijowska K, Dąbrowska E, Pietruska M. Effect of oxidants and antioxidants on oral health. Med Og Nauk Zdr. 2020; 26(2): 87-93. doi: $10.26444 / \mathrm{monz} / 122255$

\section{Abstract}

Introduction. Oxidation-reduction processes are an element of the majority of biological processes. An excess of free radicals (FR) and reactive oxygen species (ROS) leading to the development of oxidative stress are the cause of many general and local diseases, such as: diabetes, rheumatiod arthritis, atherosclerosis, periodontal diseases and diseases of other elements of the masticatory organ. The sources of free radical to which the oral cavity is exposed are the air, water, food, stimulants, drugs, and other xenobiotics. Constant exposure to FR has led to the development in the oral cavity of antioxidative defence mechanisms. Simultaneously, the provision to the oral cavity environment of anti-oxidants, such as: vitamins $\mathrm{C}$ and $\mathrm{E}$, carotenoids, flavonoids, reduces oxidative stress in the oral cavity environment.

Objective. The aim of the study is presentation of the current state of knowledge concerning the effect of oxidants and anti-oxidants on the oral cavity environment.

Materials and method. Based on scientific literature in the past few years, the results of studies concerning oxidationreduction processes in the oral cavity environment were analyzed, and endogenous and exogenous factors for oxidation, as well as anti-oxidation discussed. Etiologic factors of the pathogenic processes were indicated in the course of oxidative stress, and the possibilities of its reduction due to antioxidants.

Conclusions. Oxidative stress as an etiologic factor of pathological processes in the oral cavity may be balanced or weakened as a result of the action of antioxidation mechanisms of endogenous origin (salivary protective components), and exogenous contained in food and medicinal products. This creates the possibility for development of prophylactic programmes in oral diseases.

\section{Key words}

oral health, antioxidants, oxidation-reduction processes

\section{Streszczenie}

Wstęp. Procesy oksydacyjno-redukcyjne są elementem większości procesów biologicznych. Nadmiar wolnych rodników (WR), w tym aktywnych form tlenu (RFT), prowadzących do powstania stresu oksydacyjnego jest przyczyną powstania wielu chorób o zasięgu ogólnym lub miejscowym, takich jak: cukrzyca, reumatoidalne zapalenie stawów, miażdżyca, choroby przyzębia i innych elementów narządu żucia. Źródła wolnych rodników, na które narażona jest jama ustna, to powietrze, woda, pokarmy, używki, leki i inne ksenobiotyki. Ciągłe narażenie na WR doprowadziło do wykształcenia się w jamie ustnej antyoksydacyjnych mechanizmów obronnych. Jednocześnie dostarczenie do środowiska jamy ustnej antyoksydantów, takich jak: witaminy C, E, karotenoidy, flawonoidy, polifenole, zmniejsza stres oksydacyjny w środowisku jamy ustnej.

Cel pracy. Celem niniejszej pracy jest przedstawienie aktualnego stanu wiedzy dotyczącego wpływu oksydantów i antyoksydantów na środowisko jamy ustnej.

Materiał i metody. Na podstawie literatury naukowej ostatnich lat dokonano analizy wyników badań na temat procesów oksydacyjno-redukcyjnych w środowisku jamy ustnej. Omówiono czynniki endogenne i egzogenne zarówno oksydacji, jak i antyoksydacji. Wskazano na czynniki etiologiczne procesów chorobowych w przebiegu stresu oksydacyjnego oraz możliwości jego obniżenia dzięki antyoksydantom.

Podsumowanie. Stres oksydacyjny jako czynnik etiologiczny procesów chorobowych w jamie ustnej może być zrównoważony lub osłabiony w wyniku działania mechanizmów antyoksydacyjnych pochodzenia endogennego (elementy obronne śliny) i egzogennych zawartych w pokarmach i produktach medycznych. Stwarza to możliwości ułożenia programów profilaktycznych chorób jamy ustnej.

\section{Słowa kluczowe}

zdrowie jamy ustnej, oksydanty, antyoksydanty, procesy oksydoredukcyjne
Address for correspondence: Zofia Natalia Dąbrowska, Doctoral Studies Medical Faculty of the Medical University of Bialystok, Department of Periodontal and Oral Mucosa Diseases UMwB, Białystok, Poland, ul. Waszyngtona 13, 15-269, Białystok, Poland

E-mail: zofia.nat.dabrowska@gmail.com

Received: 15.04.2020; accepted: 11.05.2020; first published: 22.05 .2020

\section{INTRODUCTION}

In the majority of publications concerning the state of oral health, the problem of the content of monosaccharides in food and the state of oral health is raised. However, the 
number of determinants of the state of oral health may be larger, and those concerning general causes of morbidity and mortality of the population with respect to oral health cannot be omitted. This attitude results from the fact that the masticatory organ is not an isolated organ, but contains all the structural and physiological components characteristic of the whole body. Oxidation-reduction processes are an element of the majority of biological processes. An excess of free radicals (FR), including reactive oxygen species (ROS), leading to the occurrence of oxidative stress, is the cause of many general or local diseases, such as: diabetes, rheumatoid arthritis, atherosclerosis, periodontal diseases and diseases of other elements of the masticatory organ. The sources of free radicals to which the oral cavity is exposed are the air, water, food products, stimulants, drugs, and other xenobiotics. Constant exposure to FR has lead to the development of antioxidant protective mechanisms in the oral cavity. At the same time, provision to the oral cavity environment of anti-oxidants, such as: vitamins $\mathrm{C}$ and $\mathrm{E}$, carotenoids, flavonoids, and polyphenols, reduces oxidative stress in the oral cavity environment.

For the majority of organisms, oxygen is indispensable for life. However, when there occurs in the environment an excess of reactive oxygen species (ROS) in the form of oxidative stress, cells are destroyed, which leads to the development of many pathological processes. Organisms have developed protective mechanisms against the toxic effect of oxygen, represented by discoveries established by the 2019 Nobel Prize winners Kaelin Jr., Sir Peter J. Ratcliffe and Gregg L. Semenza. Studies by these Nobel laureates allowed an understanding of the way in which the levels of oxygen exert an effect on cell metabolism and physiological functions. These findings also paved the way for new strategies in control of diseases of the cardiovascular, nervous, skeletal systems, kidney damage, as well as in the pathogenesis of oral diseases $[1,2,3]$.

Despite the toxic effect of free radicals, human cells and tissues are not damaged at each contact with ROS due to complex protective mechanisms. These mechanisms include antioxidant enzymatic systems - peroxidase, catalase, superoxide dismutase, myeloperoxidase, and non-enzymatic systems - reduced glutathione, acute phase proteins, cysteine, ascorbic acid, alpha tocopherol, beta-carotene, retinol, uric acid, and methionine [4].

\section{OBJECTIVE}

The aim of the study is presentation of the current state of knowledge concerning the effect of oxidants and antioxidants on the oral environment.

\section{MATERIALS AND METHOD}

Based on the scientific literature of recent years, the results of studies concerning oxidation-reduction processes in the oral cavity environment were analyzed, and endogenous and exogenous factors for oxidation, as well as anti-oxidation discussed. Etiologic factors of the pathogenic processes were indicated in the course of oxidative stress, and the possibilities of its reduction due to antioxidatns.

The human oral cavity is the site where the protective mechanisms of the body respond to the occurrence of oxidative stress. This is possible due to the biochemical properties of saliva secreted bythe major and minor salivary glands. According to the results of research, saliva produced by the parotid glands shows the highest antioxidant capacity [5].

Endogenous antioxidant defence - saliva components. Saliva performs a wide range of functions which may be divided into 5 main categories: lubrication, buffering and clearance, maintenance of tooth integrity, antibacterial activity, as well as digestion and taste perception [6]. Saliva consists of over $99 \%$ of water, while the rest consists of electrolytes which provide a buffer capacity. Low molecular weight nitrogen compounds, hormones and proteins, such as immunoglobulins (mainly IgA, IgG and IgM), enzymes, and other proteins responsible for the protection of the oral cavity against disruption of its ecosystem are also present $[6,7]$. An increased amount of free radicals may be the result of inflammatory processes taking place in the oral cavity, and neutrophils, among others, are responsible for their production in the process of oxidative burst. Neutrophils are the first cells recruited in large amounts to the inflammation sites where, apart from antimicrobial action, they perform pro-inflammatory as well as anti-inflammatory functions in order to balance the immune response $[8,9]$. Saliva performs many important functions in the human body, including endogenous antioxidant defence against free radicals (FR), and reactive oxygen species (ROS).

Antioxidants present in saliva include antioxidant enzymes (salivary peroxidase (Px), catalase (CAT)), myeloperoxidase (MPO), as well as non-enzymatic antioxidants, such as uric acid (UA) $[10,11]$. A very important salivary enzyme is peroxidase, the enzyme which while cooperating with hydrogen peroxide ${ }_{\mathrm{H} 2 \mathrm{O} 2}$ oxygenates many substrates. Salivary peroxidase is the enzyme produced by the ductal secretory cells of the major salivary glands which, together with thiocyanates and hydrogen peroxide, forms the salivary peroxidase system. It catalyses thiocyanides, bromides and iodides present in saliva, and also deactivates the hydrogen peroxide produced by oral microorganisms, e.g. streptococci. The subsequent important component of saliva showing both bactericidal and bacteriostatic effect, participating in, among others, $\mathrm{H}_{2} \mathrm{O}_{2}$ concentration control is catalase, an oxidoreductive enzyme catalyzing hydrogen peroxide decomposition to water and oxygen. Catalase is a biofunctional enzyme which may play the role of catalase or peroxidase. In the environment with a high concentration of hydrogen peroxide catalase activity prevails, consisting in catalyzing hydrogen peroxide dismutase reaction to molecular oxygen and water. Thus, catalase does not directly participate in the elimination of free radicals; however, by the deactivation of hydrogen peroxide it does not permit its transformation to hydroxyl radical in the Fenton reaction $[12,13]$.

An equally important enzyme responsible for oxidoreductive balance is myeloperoxidase, the basic component of azurophilic granules in neutrophils. In the degranulation process there occurs a release of MPO inside the phagosome where, together with hydrogen peroxide and $\mathrm{Cl}_{2}$ Ions, it forms the system responsible for the production of a compound with strong bactericidal properties, to which belong: hypochlorous acid, chloroamines, hydroxyl radical, singlet oxygen and ozone. The primary product of oxidation reaction of $\mathrm{Cl}_{2}$ chloride ions by $\mathrm{H}_{2} \mathrm{O}_{2}$ In the reaction catalyzed by MPO, is a very strong oxidant (bactericidal compound produced by neutrophils) hypochlorous acid - $\operatorname{HOCl}[14,15]$. Uric acid 
plays a very important role in the functioning of the antioxidant barrier in saliva (approx. 70\%). Its role is sweeping out superoxide anion radical and hydroxyl radical $[16,17]$.

Exogenous factors with oxidative properties - tobacco, fluorides, chlorhexidine, cosmetic dental filling materials. Apart from the above-mentioned endogenous factors, exogenous factors also exert an effect on the oxidoreductive balance in the oral environment. They may demonstrate pro-oxidative properties: tobacco, fluorides, chlorhexidine, dental filling materials, or anti-oxidative properties: zinc, vitamin $\mathrm{C}$ and $\mathrm{E}$, flavonoids, polyphenols, ozone.

Tobacco smoking. Exerts an adverse effect on the oxidant-antioxidant balance in the saliva. According to Munther [18], total concentrations of antioxidants in the saliva were significantly higher in non-smokers, compared to smokers. According to the researcher, cigarette smoking can change the total activity of antioxidants in the saliva Cigarettes contain a large amount of free radicals which, in the oral environment, may increase oxidative stress among smokers and minimize the activity of antioxidants. Among the most dangerous components of tobacco is cadmium which accumulates in tobacco leaves. One cigarette contains $1 \div 2 \mu \mathrm{g}$ cadmium, on average, of which approximately $10 \%$ penetrates into the lungs during smoking. High concentration of cadmium, apart from pro-oxidative action, causes disorders in the metabolism of the ions of zinc, calcium, and iron, leading to osteomalacia or demineralization of bones [19]. Production of reactive oxygen species (ROS) induced by Cd may be responsible for its toxic effect in many tissues and organs, especially in the oral cavity. This metal participates in the production of various radicals, including superoxide radical, hydroxyl radical, and nitric oxide. Some studies have also confirmed the generation of hydrogen peroxide, which, in turn, may be a considerable source of radicals via the Fenton and Haber-Weiss reaction. Analyses of gene expression showed that chronic exposure of the environment to Cd considerably modifies the expression of 217 genes regulating apoptosis, cell cycle, response to stress, and immune response [20]. In oxidative stress in cells induced by $\mathrm{Cd}$ it most probably mediates the exchange of transition metals, and causes oxidation of lipids and proteins, and oxidative DNA damage in cells $[21,22]$. In their study Dąbrowski et al. observed that exposure to cadmium weakened the enzymatic antioxidant barrier (glutathione peroxidase, superoxide dismutase and catalase), and also decreased the concentrations of the main non-enzymatic antioxidants, such as reduced glutathione, leading as a result to the reduction of the total antioxidant status (TAS) in the submandibular salivary gland of rats [23]. Clinical examinations in humans showed that in the oral cavity tobacco components generate pre-cancerous states, cause long healing of wounds, discoloration of tooth and periodontal tissues, and taste disturbance by oxidation $[24,25,26,27]$. Considering the prognoses that the expose of the general population to this metal will be increasing, effective methods for preventing its negative effects are being sought. One of these methods is the use of the antioxidant potential of polyphenolic compounds and the capacity of these compounds for the complexation of $\mathrm{Cd} 2$ ions [28].

Fluorides. Used in mass, group, and individual methods of prevention of dental caries [29]. The source of fluorides are tea leaves, fish meat, fluoridated water, milk and salt; toothpaste, fluoride varnishes and gels, as well as tablets and drops [30]. The oral supply of an optimal dose of fluoride during the development of teeth causes an increase in the fluoride content in the surface layer of enamel, enabling the formation of a stable apatite crystal lattice. Fluoride participates in pre-eruptive maturation of enamel, which involves removing water and proteins from the primary enamel [31]. At each stage, an excessive, toxic supply of fluorides may cause enamel fluorosis by calcium homeostasis disorders [32]. Many changes caused by fluoride are associated with cell/matrix interaction during teeth formation. At an early stage of maturation, the relative amount of amelogenin proteins increase in fluorinated enamel in a dose-dependent way. It seems that this results from the delay in the removal of amelogenins in the course of enamel maturation. The exogenous effect of fluoride after the eruption of teeth consists in the limitation of the effect of caries-causing bacteria on the enamel by reducing the production of acids, and reduction of the deposition of a bacterial plaque on the tooth surface by interfering with the synthesis of extracellular bacterial polysaccharides. It inhibits carbohydrate metabolism in the bacterial cell, among others, by decreasing enolase activity and impairment of glucose transport inside the bacteria, interfering with the formation of intracellular spare polysaccharides [33]. Fluorides, by supporting remineralization - the presence of fluoride ions attracts calcium and phosphates - form a new tooth mineral [31].

Apart from the undoubtedly favourable effect in the prevention of caries, fluorides generate oxidative stress and a decrease in the activity of antioxidant enzymes. During the last few years, a large number of reports have been published concerning the effect of fluorides on the cellular respiration process and free radical reactions related with it. An inducing effect of the fluoride ion on superoxide radical synthesis has been shown. The mechanism of this action consists probably in the initiation of so-called oxidative burst. Lu et al. in their study found that sodium fluoride $(\mathrm{NaF})$ caused oxidative stress and apoptosis. Oxidative stress induced by $\mathrm{NaF}$ was accompanied by an increase in reactive oxygen species (ROS) and malondialdehyde (MDA), as well as by a decrease in the level of mRNA expression and superoxide dismutase activity (SOD), catalase (CAT), glutathione (GSH), glutathione peroxidase (GSH) -PX), and glutathione S-transferase (GST) [34]. Thus, the beneficial anti-caries properties of fluorides, according to their concentration and duration of application, may temporarily disrupt the oxidation-reduction potential in the oral cavity.

Chlorhexidine (CHX). Present primarily in mouthwashes, gels, toothpastes and varnishes [35]. It act as both a dental plaque inhibitor and an independent anti-inflammatory agent. CHX possesses bactericidal and bacteriostatic potential. There is high quality evidence for a considerable reduction of dental plaque due to mouth rinsing with chlorhexidine [36]. Its bactericidal effect results from damage to the cell membrane of bacteria and, in consequence, loss of intracellular material, such as potassium in low concentrations, or by inhibition of respiration and loss of nucleic acids in high concentrations.

Chlorhexidine inhibits glucosyltransferase and 2-phosphoenolopyruvate phosphotransferase which an enzyme important for the functioning and maintenance of the bacterial glycolytic pathway. Among the mechanisms of action of chlorhexidine its pro-oxidative properties are mentioned. $\mathrm{Ou}$ et al. investigated the effect of CHX on immortalized 
odontoblast-like cells (MDPC-23). In their experiment, after three days of treatment with $\mathrm{CHX}$, an obvious increase was observed in intracellular reactive oxidants [37]. According to Proksch et al., in osteoblasts, CHX induces toxicity by promoting the total amount of reactive oxidants, which may result in further impairment of osteoblasts, such as loss of cellular structure or DNA damage [38]. However, the undesirable effects of preparations containing $\mathrm{CHX}$ are also important. Among the most frequent side-effects of the use of CHX should be mentioned: brown-black tooth discoloration, mucosal discoloration, discoloured tongue, discolouration of fillings and dentures, increased supragingival calculus formation, exfoliation of the mucous epithelium, irritation of the mucosa, and altered taste. For these reasons, $\mathrm{CHX}$ cannot be applied for a long period of time [39]. Despite its many adverse effectsm chlorhexidine still remains the most effective substance limiting the development of periopathogenic bacteria which are the etiologic factor of periodontal disease.

Composite materials. Most commonly applied today in conservative dentistry for the restoration of tooth tissues damaged by caries. In 2012, a study was conducted within the project 'Monitoring of oral health among the Polish population in the years 2010-2012', which showed that $64.4 \%$ of the Polish population of 6 -year olds have more teeth damaged by caries, and only $20 \%$ of 12 -year-olds have no caries. Among the population aged 18 , caries is a frequent phenomenononly $3.9 \%$ of them are free from caries. The percentage of persons aged 18 with a filling covering one tooth surface is $58.2 \%$ in females and $60.2 \%$ in males.

The presence of composite fillings may alter the protective properties of saliva. Resin monomers are among the components with such properties, of which TEGDMA, Bis-GMA, HEMA and UDMA are the most commonly used. A study conducted by et al. Dem Y1ldiz onstrated that TEGDMA depletes glutathione, which plays a considerable role in the maintenance of oxidant-antioxidant balance. They also found that the activity of antioxidant enzymes, such as superoxide dismutase, decreased, whereas the concentration of MDA (malondialdehyde - lipid peroxides indicator) increased on day seven after the use of composite materials containing TEGDMA in the oral cavity, which is evidence of enhanced lipid peroxidation. This suggests that monomers in the filling installed increase DNA oxidation [40].

Exogenous factors with antioxidation properties - zinc, vitamin $\mathrm{C}$, vitamin $\mathrm{E}$, flavonoids, polyphenols, ozone. Zinc is a necessary trace element which acts as a co-factor in approximately 300 catalytic enzymes, and is required for the structural and functional integrity of cells. It participates in many physiological functions, emphasizing its effect as an antioxidant and as a part of other proteins related with antioxidants [41]. It is supplied to the body mainly with diet. Food products of animal and plant origin are rich in zinc, i.e.: meat, eggs, liver, oysters, as well as pumpkin and sunflower seeds, wheat germs, wheat bran, onions and garlic. The World Health Organization (WHO) recommends a daily intake of zinc of $9.4-10 \mathrm{mg}$ in females, and $6.5-7.1 \mathrm{mg}$ in males [42]. The physiologic level of zinc inhibits the production of reactive oxygen species, such as superoxide anion $\left(\cdot \mathrm{O}^{-}\right)$, hydrogen peroxide $\left(\mathrm{H}_{2} \mathrm{O}_{2}\right)$ and hydroxyl radical $(\mathrm{OH} \cdot)$, as well as reactive forms of nitrogen, including peroxynitrite [43]. The antioxidative effect of zinc may be caused by the direct effect of zinc ions, its structural role in antioxidant proteins and modulation of metallothionein induction. The direct antioxidative effect of $\mathrm{Zn}$ ions is associated with its binding to thiol groups, in this way protecting them against oxidation. Zinc deficiency in vascular endothelial cells enhances inflammatory response via cytokines and lipids, probably through mechanisms related with an increased cellular oxidative stress. In turn, zinc supplementation plays a protective role against damage to the vascular system. Mechanisms by which zinc protects blood vessels include regulation of $\mathrm{Nrf} 2$, transcription factor important for the expression of the genes encoding antioxidation enzymes, and for the induction and expression of metallothionein $[44,45]$.

A study carried out by Kostecka-Sochon et al. indicated that administration of zinc to animals during exposure to $5 \mathrm{mg}$ or $50 \mathrm{mg} \mathrm{Cd} / \mathrm{dm}^{3}$ totally inhibited cadmium, induced an increase in the levels of LPO (lipids peroxidation) and $\mathrm{H}_{2} \mathrm{O}_{2}$, and a decrease in the level of GSH (glutathione) in the sublingual tissue of the salivary gland, which allowed the conclusion that zinc supplementation reduces oxidative stress in this gland [46]. Apart from antioxidation properties, zinc is also willingly used in the control of unpleasant mouth odour caused by volatile sulfur compounds - so-called halitosis.

Vitamin C (ascorbic acid) is one of the most commonly orally administered antioxidants. Vitamin $\mathrm{C}$ is present in plant products, and its especially high content is found in: leaf parsley, nettle herb, rosehips, broccoli and pepper. Apart from vitamin C, vitamin E (a-tocopherol) also reacts rapidly with free radicals produced in metabolic processes, showing antioxidation properties [47]. Vitamin C plays a protective role for biomolecules, protecting them against damage caused by oxidants produced during basic cell metabolism, and also as a result of exposure to toxins and contaminations. In such cases, its effect is revealed as a highly effective antioxidant possessing capability for easy donation of electrons [48]. Vitamin C is an important vitamin, soluble in water, and acts synergistically with vitamin $\mathrm{E}$, which may reduce the tocopheroxyl radical and oxidized form of $\alpha$-tocopherol back to $\alpha$-tocopher [49]. An antioxidative effect of vitamin $\mathrm{C}$ was confirmed by Abdullah et al, who investigated the oxidative effect of hydrogen peroxide on human lymphocytes. The researchers found that hydrogen peroixide induced $78 \%$ of DNA damage in lymphocytes, whereas an addition of ascorbic acid decreased DNA damage by $17 \%$, compared to the control group [50]. Vitamin $\mathrm{C}$ is not only a strong antioxidant against free radicals, but simultaneously, in high doses, shows pro-oxidation activity in the Fenton reaction, the process in which free radicals are produced [51]. Again, the favourable or unfavourable effect of dietary supplementation depends on the dose.

Vitamina $\mathrm{E}$ is an essential microcomponent of human nutrition, needed for the maintenance of the integrity of cellular membranes. Vitamin E ( $\alpha$-tocopherol) is the most important lipid antioxidant in the cell membranes and subcellular organelles. Its sources include: plant oils, nuts, seeds, almonds, peanuts, olives, palm oil, rape, sweet corn and soya. It is constructed of four tocopherol isomers, reacts directly with FR and disrupts lipid peroxidation by capturing substances reactive with thiobarbituric acid. It shows antioxidant properties, mainly with reespect to lipids, because it breaks the avalanche chain of peroxidation reactions. Cells treated with vitamin $\mathrm{E}$ demonstrated a considerable antioxidation 
capability, compared to he control groups. The researchers posed the hypothesis that vitamin E supplementation may provide a protective effect against damage of vascular endothelial cells induced by PZ2, 5 [52]. Its antioxidation properties are willingly used in the treatment of periodontal diseases, where the amount of free radicals is reduced which are produced as a result of inflammatory processes caused by plaque bacteria. According to Ji-Youn et al. the administration of vitamins $\mathrm{E}$ and $C$ resulted in the reduction of the value of the Gingival index (GI), both after 4 weeks and after 8 weeks from the initial value [53].

Flavonoids are the subsequent group of antioxidants present in the oral cavity. Flavonoids are bioactive organic compounds, which belong to the group of polyphenols, naturally occurring in plants which are components of daily human food. They serve mainly as dyes, but also show an antioxidative effect [54]. Natural antioxidants, such as flavonoids, phenols and tannins, prevent diseases related with oxidative stress, such as diabetes, cancer, inflammatory processes, and other pathological conditions. To-date, more than 4,000 flavonoids have been discovered in plants, fruits and vegetables, and most often found in seeds, citrus fruits, olive oil, tea, chocolate, and red wine. From the pharmacological aspect, flavonoids show antiviral, anti-allergic, anti-cancerous, anti-fungal, and antithrombotic effects. They exert an effect on blood vessels, i.e. flavonoids and catechines, which increase capillary resistance, and show an anti-inflammatory effect which depends on the structure of the flavonoids. Flavonoids eliminate pathological changes in capillaries, and are applied against diabetes, hypertension and atherosclerosis. The antioxidant activity of flavonoids depends on the ordering of the functional groups in the structure of the compound. Compounds containing hydroxyl groups, including flavonoids, show a number of antioxidative properties, among others, capture of free radicals and capability for metal chelation [55]. Huyut et al. confirmed that falvonoids demonstrate a better lipid peroxidation inhibiting activity than referential antioxidants, such as a-tocopherol [56]. Nwidu et al. reported that natural antioxidants present in food, such as phenolic compounds or flavonoids, may play an important role in the prevention of disorders related with oxidative stress [57]. Flavenoids are also recommended in the prophylaxis of oral cavity cancer. Administration of flavone apronine in Syrian hamsters prevented the development of oral cancer by reducing oxidative stress, and modulating the phase I and phase II detoxification cascade responsible for the biotransformation of xenobiotics [58].

Polyphenols. Possess a tremendous antioxidation potential. The sources of polyphenols are black and green tea, blueberry, olive oil, rosemary and ginger; however, chokeberry juice contains the greatest amount [55]. Black chokeberry (Aronia melanocarpa), is a shrub from the Roseaceae family and originates from North America. At present in Europe, Poland is the greatest producer of chokeberry juice. Black chokeberry is one of the richest sources of polyphenols $(2.08 \mathrm{mg} / 100 \mathrm{~g})$ and has a very strong antioxidation potential due to its components, such as anthocyanins, flavonols, phenolic acids and tannins, as well as vitamins and minerals. It was also found that chokeberry fruits contain aromatic compounds, including amydgalin, cyanogenic glycoside with almond aromas and a bitter taste. The main polyphenols in Aronia melanocarpa fruits are proanthocyanidins and anthocyanins. Proanthocyanidins are the main agent characteristic of bitter taste of chokeberries and their colour. The astringent sensation caused by chokeberry fruit is the reaction of these compounds with proteins of the mucous membrane of tongue and taste receptors. Due to a large number of hydroxyl groups $(-\mathrm{OH})$ proanthocyanidins show a considerably stronger anti-radical activity than vitamins $\mathrm{E}$ and $\mathrm{C}$. In addition, proanthocyanidins are capable of binding toxic metals and alkaloids, thus they are potentially useful for detoxication applications.

It is considered that proanthocyanidins have anti-pyrogenic, anti-hepatic, anti-viral, anti-cancer and antibacterial properties, and actively participate in the prevention of thrombosis and hardening of the blood vessels [59]. Anthocyanins constitute approx. $25 \%$ of all polyphenols present in chokeberries. These compounds are glycosides. Their reactivity allows them to capture free radicals, hence, the human body uses them as natural antioxidants. Anthocyanins strengthen blood vessels, in particular capillaries, and stimulate the production of rhodopsin which plays an important role in human vision. Aronia melanocarpa has a protective effect on many organs and systems of the human body. The beneficial effect of these compounds in various diseases and states is the results of their strong antioxidant potential [60, which a the antioxidant effect of polyphenols may manifest itself in various forms, including:

- direct reaction with free radicals and their binding by stabilizing or delocalizing unpaired electrons;

- reducing properties (release of electrons or hydrogen atoms);

- increasing the dissociation of free radicals to compounds with much lower reactivity; -

- catalyzing the reaction of transforming free radicals into neutral products;

- inhibiting the activity of a number of enzymes responsible for the production of ROS (including xanthine oxidase or myeloperoxidase);

- increasing activity of other antioxidants (e.g. fat soluble vitamins);

- chelating metal ions, e.g. $\mathrm{Cu}$ or $\mathrm{Fe}$, which serve as active inductors of free radicals;

- increase total antioxidant potential $[61,62]$.

Summing-up, the results of own study and an experimental model on animals by Dąbrowska et al. confirmed that the consumption of chokeberry products may prevent oxidative/ antioxidant imbalance induced by $\mathrm{Cd}$, and the development of oxidative stress in the parotid gland, protecting against damage of this gland by the toxic effect of cadmium [63].

Ozone. An allotropic form of oxygen applied for the disinfection of drinking water and closed spaces (ozonation), and is increasingly frequently used in medicine due to its effect as an anti-viral, anti-fungal, and anti-bacterial agent. Due to this effect, ozone therapy is applied, among others, in dentistry, dermatology, orthopaedics, surgery, gyneacology, and opthalmology [64]. The wide therapeutic use of ozone in dentistry is due to its properties: antimicrobial, stimulating the immune system, analgesic, detoxifying, anti-hypoxic, biosynthetic and biostimulant. In addition, it is applied in many branches of dentistr: in prevention, conservative dentistry (teeth whitening, treatment of dentine hypersensitivity), endodontics, paediatric dentistry, orthodontics, periodontology and the treatment of oral mucosa diseases, prosthetics and dental surgery [65]. It is able to destroy biomolecules and the cell walls 
of bacteria, damaging them by reacting with polyunsaturated fatty acids in the cell membrane, phospholipids and proteins containing methionine, cysteine and histidine [66]. Its antioxidant power is third after fluorine and persulphurization [67].

In other studies, medical ozone therapy reduced oxidative stress and testicular damage in an experimental testicular torsion model in rats. The levels of the oxidant status (TOS) and oxidative stress index (OSI) in serum increased in rats not treated for testicular torsion; however, it decreased in those which received ozone therapy. This suggests that one of the potentially beneficial effect of ozone may be minimization of tissue damage through the improvement of the activity of the antioxidant system [68]. Zhishun et al. investigated the effect of ozone pre-conditioning on the inflammatory status and oxidative stress damage on a rat kidney transplant model. They reported that ozone pre-conditioning may increase the activity of the endogenous antioxidant system. Therefore, ozone pre-conditioning may help in triggering tolerance to reactive oxidizing substances generated by certain toxic agents [69].

\section{CONCLUSIONS}

Oxidative stress as an etiologic factor of pathological processes in the oral cavity may be balanced or weakened as a result of endogenous antioxidation mechanisms in the saliva, as well as exogenous mechanisms in food and medicinal products. The above-presented knowledge should be beneficial in clinical practice, not only to dentists, but also the staff practicing other medical professions. This would allow an improvement in pro-health awareness among both medical staff and patients from the aspect of holistic medical care. Individual responsibility for own health should be constantly monitored and supplemented with up-to-date information concerning the etiologic and prophylactic mechanisms of diseases of genera, and local diseases. This creates possibilities for designing new prophylactic programmes in oral diseases, not only by the elimination of sugars or caries-causing bacteria, but also by the simultaneous use of nutrients and dietary supplements with the antioxidation properties mentioned in this study.

\section{REFERENCES}

1. Tóthová L, Kamodyová N, Cervenka T, Celec P.Salivary markers of oxidative stress in oral diseases. Frontiers in Cellular and Infection Microbiology. 2015; 5: 73. https://doi:10.3389/fcimb.2015.00073

2. Golusińska-Kardach E, Napierała M, Sokalski J, Kardach H, Florek E. Choroby przyzębia u palaczy tytoniu a parametry stresu oksydacyjnego. Przegląd Lekarski 2015; 72(10): 584-587.

3. Konopka T, Gmyrek-Marciniak A, Kozłowski Z, Kaczmarek U, Wnukiewicz J. Potencjał antyoksydacyjny śliny u pacjentów z zapaleniem przyzębia i rakiem płaskonabłonkowym dna jamy ustnej. Dental and Medical Problems. 2006; 43: 354-362.

4. Iwanek P. Biologiczne podstawy działaniu ozonu na florę jamy ustnej. Roczniki Pomorskiej Akademii Medycznej w Szczecinie 2007; 53(3): 41-44.

5. Roblegg E, Coughran A, Sirjani D. Saliva: an all-rounder of our body. Eur J Pharm Biopharm. 2019; 142: 133-141. https://doi:10.1016/j. ejpb.2019.06.016

6. Humphrey SP,Williamson RT.A review of saliva: normal composition, flow, and function.J Prosthet Dent.2001; 85(2): 162-169. https:// doi:10.1067/mpr.2001.113778

7. Gornowicz A, Tokajuk G, Bielawska A. The assesment of sIgA, histatin-g, and lactoperoxidase levels in saliva of adolescents with dental caries. Medical Science Monitor. 2014; 20: 1095-1100. https://doi:10.12659/ MSM.890468
8. Amulic B, Cazalet C, Hayes GL, Metzler KD, Zychlinsky A. Neutrophil function: from mechanisms to disease. Annu Rev Immunol. 2012; 30: 459-489.

9. Nathan C, Cunningham-Bussel A. Beyond oxidative stress: an immunologist's guide to reactive oxygen species. Nat Rev Immunol. 2013; 13: 349-361. https://doi:10.1038/nri3423

10. Żukowski P, Maciejczyk M, Waszkiel D. Sources of free radicals and oxidative stress in the oral cavity. Archives of Oral Biology. 2018; 92: 8-17. https://doi: 10.1016/j.archoralbio.2018.04.018

11. Knaś M, Maciejczyk M, Waszkiel D, Zalewska A. Oxidative stress and salivary antioxidants. Dental and Medical Problems. 2013; 50(4): 461-466.

12. Słotwińska S, Majkowski M. Wybielanie zębów a środowisko jamy ustnej. Nowa Stomatologia 2011; 3: 115-118.

13. Karpińska A, Gromadzka G. Stres oksydacyjny i naturalne mechanizmy antyoksydacyjne - znaczenie w procesie neurodegeneracji. Od mechanizmów molekularnych do strategii terapeutycznych. Postepy Hig Med Dosw (online), 2013; 67: 43-53. https://core.ac.uk/download/ pdf/26834030.pdf (dostęp:2020.03.24).

14. Klebanoff SJ, Kettle AJ, Rosen H, Winterbourn CC, Nauseef WM. Myeloperoxidase: a front-line defender against phagocytosed microorganisms. J Leukoc Biol. 2013; 93(2): 185-198. https://doi: 10.1189/ jlb.0712349

15. Winterbourn CC. Biological reactivity and biomarkers of the neutrophil oxidant, hypochlorous acid. Toxicology 2002; 181-182: 223-227. https:// doi:10.1016/s0300-483x(02)00286-x

16. Moore S, Calder KA, Miller NJ, Rice-Evans CA. Antioxidant activity of saliva and periodontal disease. Free Radic Res. 1994; 21(6): 417-425. https://doi:10.3109/10715769409056594

17. Gawron-Skarbek A, Prymont-Przymińska A, Sobczak A, et al. A comparison of native and non-urate total antioxidant capacity of fasting plasma and saliva among middle-aged and older subjects. Redox Rep. 2018; 23(1): 57-62. https://doi: 10.1080/13510002.2017.1392714

18. Munther S. The effects of cigarette smoking and exercise on total salivary antioxidant activity. The Saudi Dental Journal. 2019; 31(1): 31-38. https://doi:10.1016/j.sdentj.2018.09.002

19. Łabądź D, Skolarczyk J, Pekar J, Nieradko-Iwanicka B. Analysis of the influence of selected elements on the functioning of the bone tissue. Journal of Education, Health and Sport. 2017; 7(4): 202-209.

20. Nemmiche S, Oxidative Signaling Response to Cadmium Exposure. Toxicological Sciences. 2017; 156(1): 4-10. https://doi:10.1093/toxsci/kfw222

21. Nemmiche S, Guiraud P. Cadmium-induced oxidative damages in the human BJAB cells correlate with changes in intracellular trace elements levels and zinc transporters expression. Toxicology in Vitro. 2016; 37: 169-177. https://doi.org/10.1016/j.tiv.2016.09.014

22. Pathak N, Khandelwal S. Oxidative stress and apoptotic changes in murine splenocytes exposed to cadmium.Toxicology.2006; 220(1): 26-36. https://doi.org/10.1016/j.tox.2005.11.027

23. Dąbrowski A, Onopiuk B, Car H, Onopiuk P, Dąbrowska Z, Rogalska J, Brzóska MM, Dąbrowska E. Beneficial Impact of an Extract from the Berries of Aronia melanocarpa L. on the Oxidative-Reductive Status of the Submandibular Gland of Rats Exposed to Cadmium. Antioxidants. 2020; 9(2): 185. https://doi.org/10.3390/antiox9020185

24. Stanfill SB, Connolly GN, Zhang L, Jia LT, Henningfield JE, Richter $\mathrm{P}$, et al. Global surveillance of oral tobacco products: Total nicotine, unionised nicotine and tobacco-specific N-nitrosamines.Tob Control. 2011; 20(3): e2. https://doi:10.1136/tc.2010.037465

25. Akinkugbe AA, Sanders AE, Preisser JS, Cai J, Salazar CR, Beck JD. Environmental tobacco smoke exposure and periodontitis prevalence among nonsmokers in the hispanic community. Health Study/Study of Latinos.Community dentistry and oral epidemiology. 2017; 45(2): 168-177. https://doi: 10.1111/cdoe.12275

26. Akinkugbe AA, Slade GD, Divaris K, Poole C. Systematic Review and Meta-analysis of the Association Between Exposure to Environmental Tobacco Smoke and Periodontitis Endpoints Among Nonsmokers. Nicotine \& tobacco research: official journal of the Society for Research on Nicotine and Tobacco. 2016; 18(11): 2047-2056. https://doi: 10.1093/ntr/ntw105

27. Dietrich T, Walter C, Oluwagbemigun K, et al. Smoking, Smoking Cessation, and Risk of Tooth Loss: The EPIC-Potsdam Study. J Dent Res. 2015; 94(10): 1369-1375. https://doi:10.1177/0022034515598961

28. Brzóska MM, Gałażyn-Sidorczuk M, Jurczuk M, Tomczyk M. Protective effect of Aronia melanocarpa polyphenols on cadmium accumulation in the body: a study in a rat model of human exposure to this metal. Current Drug Targets. 2015; 16(13): 1470-1487. https://doi10.2174/138 9450116666150102121708

29. Kaczmarek U, Jackowska T, Mielnik-Błaszczak M, Jurczak A, Olczak-Kowalczyk D. Indywidualna profilaktyka fluorkowa u dzieci 
i młodzieży - rekomendacje polskich ekspertów. Nowa Stomatologia. 2019; 24(2): 70-85. https://doi:10.25121/NS.2019.24.2.70

30. O’Mullane DM, Baez RJ, Jones S, Lennon MA, Petersen PE, RuggGunn AJ, Whelton H, Whitford GM. Fluoride and Oral Health. Community Dental Health. 2016; 33(2): 69-99. https:/doi:10.1922/ CDH_3707O'Mullane31

31. Kaczmarek U. Mechanizmy kariostatyczne fluoru. Czas Stomatol .2005; 58(6): 404-413.

32. Lyaruu DM, Medina JF, Sarvide S, Bervoets TJM, Everts V, DenBesten P, et al. Barrier Formation: Potential Molecular Mechanism of Enamel Fluorosis. Journal of Dental Research. 2014; 93(1): 96-102. https://doi. org/10.1177/0022034513510944

33. Sun L, Gao Y, Zhang W, Liu H, Sun D. Effect of high fluoride and high fat on serum lipid levels and oxidative stress in rabbits. Environ Toxicol Pharmacol. 2014; 38(3): 1000-1006. https://doi.org/10.1016/j. etap.2014.10.010

34.Lu Y, Luo Q, Cui H, Deng H, Kuang P, Liu H, et al. Sodium fluoride causes oxidative stress and apoptosis in the mouse liver. Aging (Albany NY). 2017; 9(6): 1623-1639. https://doi:10.18632/aging.101257

35. Kwiatkowska A, Mielczarek A, Gajewski T. Wykorzystanie olejków eterycznych w środkach do higieny jamy ustnej. Nowa Stomatol. 2017; 22(3): 148-155.

36. James P, Worthington HV, Parnell C, et al. Chlorhexidine mouthrinse as an adjunctive treatment for gingival health. Cochrane Database Syst Rev. 2017; 3: CD008676. https://doi:10.1002/14651858.CD008676.pub2.

37. Ou Q, Tan L, Huang X, Luo Q, Wang Y, Lin X. Effect of matrix metalloproteinase 8 inhibitor and chlorhexidine on the cytotoxicity, oxidative stress and cytokine level of MDPC-23. Dental Materials. 2018; 34(11): e301-e308. https://doi.org/10.1016/j.dental.2018.08.295

38. Proksch S, Strobel SL, Vach K, Abouassi T, Tomakidi P, Ratka-Kruger $\mathrm{P}$, et al. Melatonin as a candidate therapeutic drug for protecting bone cells from chlorhexidine-induced damage. J Periodontol. 2014; 85(12): 379-389. https://doi:10.1902/jop.2014.140279

39. Fiorillo L. Chlorhexidine gel use in the oral district: a systematic review. Gels. 2019; 5(2): 31. https://doi:10.3390/gels5020031

40. Yıldız M, Alp HH, Gül P, Bakan N, Özcan M. Lipid peroxidation and DNA oxidation caused by dental filling materials. Journal of Dental Sciences. 2017; 12(3): 233-240. https://doi.org/10.1016/j.jds.2017.02.002

41. Li B, Tan Y, Sun W, Fu Y, Miao L, Cai L. The role of zinc in the prevention of diabetic cardiomyopathy and nephropathy. Toxicol Mech Methods. 2013; 23(1): 27-33. https://doi: 10.3109/15376516.2012.735277

42. Gapys B, Raszeja-Specht A, Bielarczyk H. Rola cynku w procesach fizjologicznych i patofizjologicznych organizmu. Diagn Lab. 2014; 50(1): 45-52.

43. Maywald M, Rink L. Zinc homeostasis and immunosenescence. J Trace Elem Med Biol. 2015; 29: 24-30. https://doi: 10.1016/j.jtemb.2014.06.003

44. Oteiza PI. Zinc and the modulation of redox homeostasis. Free Radic Biol Med. 2012; 53(9): 1748-1759. https://doi: 10.1016/j.freeradbiomed.2012.08.568

45. Korkmaz-Icöz S, Atmanli A, Radovits T, Li S, Hegedüs P, Ruppert M, Brlecic P, Yoshikawa Y, Yasui H, Karck M, Szabó GJ. Administration of zinc complex of acetylsalicylic acid after the onset of myocardial injuryprotects the heart by upregulation of antioxidant enzymes. J Physiol Sci. 2016; 66(2): 113-125. https://doi:10.1007/s12576-015-0403-6

46. Kostecka-Sochoń P, Onopiuk BM, Dąbrowska E. Protective Effect of Increased Zinc Supply against Oxidative Damage of Sublingual Gland in Chronic Exposure to Cadmium: Experimental Study on Rats. Oxid Med Cell Longev. 2018; 2018: 3732842. https://doi:10.1155/2018/3732842

47. Yoshino F, Yoshida A. Effects of blue-light irradiation during dental treatment. Japanese Dental Science Review. 2018; 54(4): 160-168. https:// doi: 10.1016/j.jdsr.2018.06.002

48. Mullak A, Hołysz H, Totoń E, Rubiś B. Witamina C jako modulator skuteczności przeciwnowotworowej. Farmacja Współczesna. 2018; $11 ; 245-253$

49. Xiao-Yan L, Zi-Chuan Z. Assessment of serum malondialdehyde, uric acid, and vitamins $C$ and $E$ levels in patients with recurrent aphthous stomatitis. Journal of Dental Sciences. 2016; 11(4): 401-404. https:// doi:10.1016/j.jds.2016.06.002

50. Abdullah HN, Al-Asadi SA, Saleh MA. Effect of Ascorbic Acid (Vitamin C) on H2O2 Induced Oxidative DNA Damage in Human Lymphocytes Estimated by Comet Assay. Diyala Journal For Pure Science. 2018; 14(1): 204-217. https://doi:10.24237/djps.1401.377C

51. Galli F, Azzi A, Birringer M, Cook-Mills JM, Eggersdorfer M, Frank J, Cruciani G, Lorkowski S, Ozer NK. Vitamin E: Emerging aspects and new directions. Free Radic Biol Med. 2017; 102: 16-36. https:// doi:10.1016/j.freeradbiomed.2016.09.017
52. Bo L, Jiang S, Xie Y, Kan H, Song W, Zhao J. Effect of Vitamin E and Omega-3 Fatty Acids on Protecting Ambient PM2.5-Induced Inflammatory Response and Oxidative Stress in Vascular Endothelial Cells.PLoS One. 2016; 11(3): e0152216. https://doi:10.3390/ijms17101745doi:10.1371/ journal.pone.0152216

53. Ji-Youn H, Jung-Seok L, Seong-Ho C, Hyun-Seung S, Jung-Chul P, Seung-Il S, Jong-Hyuk C. A randomized, double-blind, placebo-controlled multicenter study for evaluating the effects of fixed-dose combinations of vitamin C, vitamin E, lysozyme, and carbazochrome on gingival inflammation in chronic periodontitis patients. BMC Oral Health. 2019; 19(40). https://doi.org/10.1186/s12903-019-0728-2 .https:// bmcoralhealth.biomedcentral.com/articles/10.1186/s12903-019-07282\#article-info (dostęp:2020.03.23).

54. Głodo P, Matejko B. Ciemna czekolada jako bogactwo flawonoidów - sprzymierzeńców w prewencji i leczeniu wielu schorzeń. Probl Hig Epidemiol. 2019; 100(2): 82-88.

55. Kałwa K. Właściwości antyoksydacyjne flawonoidów oraz ich wpływ na zdrowie człowieka. Kosmos problemy nauk przyrodniczych. 2019; 68(1): 153-159. https://doi.org/10.36921/kos.2019_2490

56. Huyut Z, Beydemir S, Gülçin I. Antioxidant and Antiradical Properties of Selected Flavonoids and Phenolic Compounds. Biochemistry Research International. 2017; 2017: 7616791. https://doi:10.1155/2017/7616791

57. Nwidu LL, Elmorsy E, Oboma YI, Carter WG. Hepatoprotective and antioxidant activities of Spondias mombin leaf and stem extracts against carbon tetrachloride-induced hepatotoxicity. Journal of Taibah University Medical Sciences. 2018; 13(3): 262-271. https://doi:10.1016/j. jtumed.2018.03.006

58. Gómez-García FJ, López-Jornet MP, Álvarez-Sánchez N, Castillo-Sánchez J, Benavente-García O, Vicente Ortega V. Effect of the phenolic compounds apigenin and carnosic acid on oral carcinogenesis in hamster induced by DMBA. Oral Dis. 2013; 19(3): 279-286. https:// doi:10.1111/j.1601-0825.2012.01975.x

59. Borowska S, Brzóska MM. Chokeberries (Aronia melanocarpa) and Their Products as a Possible Means for the Prevention and Treatment of Noncommunicable Diseases and Unfavorable Health Effects Due to Exposure to Xenobiotics. Compr Rev Food Sci Food Saf. 2016; 15(6): 982-1017. https://doi:10.1111/1541-4337.12221

60. Fang J. Bioavailability of anthocyanins. Drug Metab Rev. 2014; 46(4): 508-20. https://doi:10.3109/03602532.2014.978080

61. Mężyńska M, Brzóska MM. Review of polyphenol-rich products as potential protective and therapeutic factors against cadmium hepatotoxicity. Journal of Applied Toxicology. 2019; 39(1): 117-145. https:// doi:10.1002/jat.3709

62. Borowska S, Brzóska MM, Tomczyk M. Complexation of bioelements and toxicmetals by polyphenolic compounds-implications for heslth. Current Drug Targets. 2018; 19(14): 612-638. https://doi:10.2174/1389 450119666180403101555

63. Dąbrowska Z, Dąbrowska E, Onopiuk B, Onopiuk P, Orywal K, Mroczko $\mathrm{B}$, Pietruska M. The Protective Impact of Black Chokeberry Fruit Extract (Aronia melaenocarpa L.) on the Oxidoreductive System of the Parotid Gland of Rats Exposed to Cadmium. Oxidative Medicine and Cellular Longevity. 2019: ID 3403264, 11pp. https://doi.org/10.1155/2019/3403264

64. Michalski K, Kulińska-Michalska MM. Ozone in medicine. Medycyna Ogólna i Nauki o Zdrowiu. 2019; 25(3): 135-137. https://doi:https://doi. org/10.26444/monz/111999

65. Mocny-Pachońska K, Kuśka-Kiełbratowska A, Skaba D, Wójcik M, Janowska-Bogacz K, Tanasiewicz M. Skuteczność zastosowania ozonu w stomatologii - przegląd piśmiennictwa. Ann Acad Med Siles. (online) 2019; 73: 69-73. http://psjd.icm.edu.pl/psjd/element/bwmeta1.element. psjd-cc8c455f-0fe1-4200-875b-d2f9a8ee90df (dostęp:2020.03.24).

66. Boch T, Tennert C, Vach K, Al-Ahmad A, Hellwig E, Polydorou O. Effect of gaseous ozone on Enterococcus faecalis biofilm-an in vitro study. Clinical Oral Investigations. 2016; 20(7): 1733-1739. https:// doi:10.1007/s00784-015-1667-1

67. Elvis AM, Ekta JS. Ozone therapy: A clinical review. J Nat Sci Biol Med. 2011; 2(1): 66-70. https://doi:10.4103/0976-9668.82319

68. Tusat M, Mentese A, Demir S, Alver A, Imamoglu M. Medical ozone therapy reduces oxidative stress and testicular damage in an experimental model of testicular torsion in rats. Int Braz J Urol. 2017; 43(6): 1160-1166. https://doi:10.1590/S1677-5538.IBJU.2016.0546

69.Zhishun W, Qi H,Yong-lian G,Xiu-heng L, Tao Q. Effect of ozone oxidative preconditioning on inflammation and oxidative stress injury in rat model of renal transplantation. Acta Cir Bras.2018;33(3):238-249 http://www.scielo.br/scielo.php?script=sci_ar ttext\&pid=S0102-86502018000300238.(dostęp:2020.03.25). https://doi. org/10.1590/s0102-865020180030000006 